\title{
Indonesian Migrant Workers Protection through the Law Number 18 of 2017: New Direction and its Implementation Challenges
}

\author{
Nabiyla Risfa Izzati* \\ DOI: https://doi.org/10.22304/pjih.v6n1.a10 \\ Submitted: September 11, 2018 | Accepted: May 15, 2019
}

\begin{abstract}
As one of the prominent sending states of migrant workers, Indonesia seeks to increase protection efforts for its citizens who work abroad through the Law Number 18 of 2017 on the Protection of Indonesian Migrant Workers (UUPPMI). The UUPPMI replaces the Law Number 39 of 2004 on the Placement and the Protection of Indonesian Migrant Workers, which was criticized since it only focused on the issue of placement without paying a lot of attention related with protection of migrant workers. This study used normative method to analyze the articles of UUPPMI and evaluate the suitability of the arrangements to the theories of worker protection. The results indicate that one of the most prominent changes in the UUPPMI is the emergence of a larger role of the government, which means that it automatically reduces the role of private sector in the mechanism of placement and protection of migrant workers. The UUPPMI delegates the responsibility to protect migrant workers to both central and regional governments, starting from before, during, and after worker's work period.
\end{abstract}

Keywords: UUPPMI, legal protection, migrant workers

\section{Arah Baru Perlindungan Pekerja Migran Indonesia melalui Undang-Undang Nomor 18 Tahun 2017 dan Tantangan Implementasinya}

\section{Abstrak}

Sebagai salah satu negara pengirim pekerja migran terbesar di dunia, Indonesia berusaha meningkatkan upaya perlindungan bagi warga negaranya yang bekerja di luar negeri melalui Undang-Undang Nomor 18 Tahun 2017 tentang Pelindungan Pekerja Migran Indonesia (UUPPMI). UUPPMI menggantikan Undang-Undang Nomor 39 tahun 2004 tentang Penempatan dan Perlindungan Tenaga Kerja Indonesia di Luar Negeri yang banyak dikritik karena hanya fokus pada masalah penempatan, bukan perlindungan.

PADJADJARAN Journal of Law Volume 6 Number 1 Year 2019 [ISSN 2460-1543] [e-ISSN 2442-9325]

Lecturer of the Department of Private Law, the Faculty of Law, Universitas Gadjah Mada, Kompleks UGM, Jalan Sosio Yustisia, Bulaksumur No.1, Karang Malang, Caturtunggal, Yogyakarta, S.H. (Universitas Gadjah Mada), LL.M. (Leiden Universiteit), nabiylarisfa@mail.ugm.ac.id. 
Penelitian ini dilakukan dengan menggunakan metode normatif, yakni dengan menelah pasal-pasal yang ada dalam UUPPMI, dan menganalisis apakah pengaturan tersebut telah berkesuaian dengan terori-teori tentang perlindungan pekerja yang ada. Hasil penelitian ini menunjukkan bahwa salah satu perubahan yang paling menonjol dalam UUPPMI adalah munculnya peran yang lebih besar dari pemerintah, yang artinya secara otomatis mengurangi peran swasta dalam mekanisme penempatan dan pelindungan pekerja migran. UUPPMI menyerahkan tanggung jawab untuk melindungi pekerja migran kepada pemerintah baik pusat maupun daerah, dimulai dari sebelum bekerja, selama bekerja, dan setelah bekerja.

Kata kunci: perlindungan hukum, pekerja migran, UUPPMI.

\section{A. Introduction}

Protection of migrant workers is a topic which inseparable from employment studies throughout the world. Globalization, which makes national boundaries increasingly blurred, causes human migration to be a common thing. Many people choose to work outside their home country to get better employment opportunities and more secure life. The people who work outside their home country are categorized as migrant workers.

Indonesia is a state that sends a significant number of migrant workers. The National Agency for Placement and Protection of Indonesian Workers (BNP2TKI) stated that in 2016, around 9 million Indonesians, both procedural and nonprocedural, were working abroad as migrant workers. The number is equivalent to 7 percent of the total Indonesian workforce. ${ }^{1}$ During the last 10 years, the number of Indonesian migrant workers has been increasing. Thus, it is clear that the migrant workers are important component of the national workforce.

The increase of labor migration reflects the limited domestic employment opportunities in Indonesia. On the other hand, migration also gives a significant economic impact on both migrant workers and the Indonesian economy. Indonesian migrant workers can earn up to six times comparing to domestic workers. In addition, for 70 percent of migrant workers, working abroad is a positive experience that helps them to improve their welfare. Migration also provides opportunities for migrant workers to acquire skills and work experience. Almost 80 percent of female migrant workers see migration as the gateway to the

\footnotetext{
The National Agency for Placement and Protection of Indonesian Workers (BNP2TKI -Badan Nasional Penempatan dan Perlindungan Tenaga Kerja Indonesia), "Data Penempatan TKI Tahun 2011 sampai dengan 2016", http://www.bnp2tki.go.id/uploads/data/data 08-02-2017 111324 Data-P2TKI tahun 2016.pdf, accessed on March 2019.
} 
paid labor market. Its impact on the Indonesian economy worth more than Rp118 trillion (US \$ 8.9 billion) in 2016, equivalent to 1 percent of Indonesia's total GDP. ${ }^{2}$

In 2004, the Indonesian government issued the Law Number 39 of 2004 on the Placement and Protection of Indonesian Migrant Workers (Placement and Protection of Indonesian Migrant Workers Law 2004). This Law is a government effort to give legal protection that is pro-migrant. Some important parts of this Law, among others, is regulating that the placement and protection of prospective Indonesian Migrant Workers (TKI) must be based on integration, equality, democracy, social justice, gender equality-and-justice, anti-discrimination, and antitrafficking.

In addition, Placement and Protection of Indonesian Migrant Workers Law also states that the government is responsible to increase efforts to protect Indonesian migrant workers abroad and guarantee that in carrying out their duties and responsibilities, they will ensure the fulfillment of the rights of prospective workers. Furthermore, the government has the duty to oversee the placement of prospective migrant workers, as well as to establish and to develop information systems for placement of prospective migrant workers abroad. The government should also make diplomatic efforts to ensure the fulfillment of the rights and protection of migrant workers optimally in the destination country and provide protection to migrant workers during the pre-departure period, placement period, and full-time placement.

After some times, the Placement and Protection of Indonesian Migrant Workers Law 2004, which was initially considered ideal to protect migrant workers, began to reap a lot of criticism. One of the biggest criticisms is rooted from the fact that this regulation emphasizes more on the placement aspect than the protection. The Law itself contained 109 articles, but only nine of are talking about the protection of migrant worker, while others are heavily regulating about placement.

In 2015, Yohana S Ambise, Minister of Women's Empowerment and Children Protection (PPPA) at the time, openly criticized the Law during a Working Meeting with the House of Representatives. Yohana said that there were at least seven weaknesses of the Law. First, the law dominated by the affair within government and the worker placement business actors (PPTKIS). Second, the Law did not contain strict-prohibition for countries that do not protect Indonesian migrant workers. Third, the Law did not provide protection for Indonesian migrant workers comprehensively, for example, not recognizing the rights of families of Indonesian migrant workers even though Indonesia has ratified the 1990 Migrant Workers Convention. Fifth, the Law did not regulate the protection of migrant workers after working abroad. Sixth, the Law raises the question about ineffectiveness of

2 World Bank, Laporan Bank Dunia Indonesia: Pekerja Global Indonesia: Antara Peluang dan Resiko, Jakarta: World Bank Group, 2017, p. III. 
supervision because the same government institution is doing all the work; starting from regulating, fostering, implementing, and overseeing the placement and the protection of migrant workers. Then, seven, the Law did not state explicitly the division of roles, functions, and responsibility of each institution related to the protection of migrant workers. ${ }^{3}$

Ministry of Social Affairs of the Republic of Indonesia in 2014 also noted that there were at least $16.68 \%$ Indonesian migrant workers which regularly exposed to various problems ranging from illness, unilateral termination of employment, sexual harassment, placement not in accordance with work agreements, workplace accidents, persecution, to capital punishment and death. This indicates that migrant workers are indeed vulnerable to social problems and still have minimum protection from national and international laws. ${ }^{4}$

The various factors above encourage the Indonesian government to form new policies to achieve better protection for its migrant workers. In recent years, the government has issued various policies to maximize the benefits of international labor migration, for examples, signing Memorandum of Understandings (MoUs) with several destination countries, making the process of migration easier, and placing special labor attaches in consulate offices in the destination countries to ensure that migrant workers are protected adequately. ${ }^{5}$ However, various incidents of violence against workers abroad show that the Indonesian Government still has not made optimal efforts to protect the migrant workers. ${ }^{6}$ For example, the Migrant Workers Network records that there are 7,600 cases concerning migrant workers that occurred throughout $2017 .^{7}$ Therefore, the government feels that there should be fundamental changes on the Indonesian migrant workers protection. After a long process, on October 25, 2017, the Law Number 18 of 2017 on the Protection of Indonesian Migrant Workers (Protection of Indonesian Migrant Workers Law 2017) was finally ratified. This Law expressly revokes the Placement and Protection of Indonesian Migrant Workers Law 2004.

The Protection of Indonesian Migrant Workers Law provides new hope in the efforts to protect Indonesian migrant workers. One of the most prominent changes is the emergence of a larger role of the government in the protection of migrant works, which automatically reduces the role of the private sector that previously

3 “Menteri Yasona Ungkap 7 Kelemahan UU TKI”. See Hotman Siregar (ed.), "Menteri Yohana Ungkap 7 Kelemahan UU TKI", http://www.beritasatu.com/nasional/287806-menteri-yohana-ungkap-7-kelemahan-uutki.html, accessed on July 2018.

4 Pusat Penelitian dan Pengembangan Kesejahteraan Sosial, Badan Pendidikan dan Penelitian Kesejahteraan Sosial, Perlindungan Sosial Pekerja Migran Bermasalah Melalui Rumah Perlindungan Trauma Center, Jakarta: Kementerian Sosial Republik Indonesia, 2015, p. 3.

World Bank, op.cit., p. 15.

6 Ibid.

7 Kompas. Id, “Tahun 2017, Kasus yang Menimpa Pekerja Migran Capai 7.600", https://kompas.id/baca/utama/2018/02/25/tahun-2017-kasus-yang-menimpa-pekerja-migran-capai-7-600/, accessed on March 2019. 
exist. In this Law, the role of the protection of Indonesian migrant workers is handed over to the central and local governments, starting from before, during, and after work. The private sector is only given the role to implement the placement of the workers. $^{8}$

In general, the Law states that the protection of Prospective Indonesian Migrant Workers and Indonesian Migrant Workers aims to ensure the fulfillment and enforcement of human rights as citizens in general, and Indonesian Migrant Workers specifically. In addition, another important goal of this law is to ensure the legal, economic, and social protections of Indonesian Migrant Workers and their families. This premise certainly looks ideal. However, does the arrangement of the Law really embodies the goals? This study wills examines the changing view about protection of migrant workers in Protection of Indonesian Migrant Workers Law, and how they address the challenges of the implementation of the protection of migrant workers.

\section{B. Protection of Indonesian Migrant Workers under the Law Number 18 of 2017 1. Workers Protection Philosophy}

The concepts of legal state, both the rechtstaat and the rule of law, were born because of state's obligation to provide recognition and protection of human rights. The concept of rechtstaat, according to Stahl, meant that a state should always organize its governmental power based on law. The concept includes several elements; one of which is the protection of human rights. ${ }^{9}$

Every legal relationship leads to rights and obligations, which are ideally regulated in provisions of a legislation. However, not all parties in given legal relationship have the same position and can maintain their rights. Therefore, state through their government, becoming a responsible party to guarantees that the rights of citizens are fulfilled; one of the ways to do it is through a legal protection mechanism. Philosophically, the Preamble of the 1945 Constitution of the Republic of Indonesia (1945 Constitution) has implied the obligation of the state to protect the people and the bloodshed of all Indonesians.

Legal protection, especially in the context of employment, is always related to the role and function of law as regulator and protector of people interests. Malinowski states that "Iaw and order pervade the tribal usages of primitive races, they govern the humdrum course of daily existence, as well as the leading acts of public life, whether these are quaint and sensational or important and venerable". ${ }^{10}$

8 See General Eludication on Law Number 18 of 2017 on Indonesian Manpower Protection [Undang-Undang Nomor 18 Tahun 2017 tentang Perlindungan Pekerja Migran Indonesia] (Manpower Protection Law).

9 Philipus M. Hadjon, Perlindungan Hukum Bagi Rakyat di Indonesia, Surabaya: PT. Nila IImu, 1987, p. 14

10 Bronislaw Malinowski, Crime and Custom in Savage Society, London: Trench, Trubner and co. Itd, 1926, p. 3. 
In general, it can be interpreted that the law does not only play a role in conditions full of violence and opposition but that law also plays a role in daily activities. ${ }^{11}$

Hadjon divides the form of legal protection into two types: preventive and repressive. Preventive legal protection is provided to prevent future disputes or the people are given opportunity to raise objections and opinions before a decision by government gets a definite form. Repressive legal protection appears after a dispute that aims to restore rights of parties who are harmed. ${ }^{12}$

In labour law perspective, the form of workers' protection in general has been regulated in the Law of Manpower and its regulations. Protection of workers is intended to guarantee the basic rights of workers/laborers and ensure equality of opportunity and treatment without discrimination on any basis to realize the welfare of workers/laborers and their families while considering the progress of the business world. Such provisions are motivated by the role of labor in national development, which is increasing and developing into various aspects of life. Therefore, workers need to be guaranteed for protection regardless of their gender background, type of work, even age of worker. This is in line with the urgency of protecting workers who have weak positions.

Legal protection against workers is carried out if the legislation in the field of labor, which requires or forces employers to act based on the legislation is really carried out by all parties. ${ }^{13}$ The emergence of such things is due to the position of workers not only in terms of juridical but also in terms of socio-economic, which allows arbitrary action of employers or employers if the government does not regulate the existence of legal protection mechanisms for these workers. ${ }^{14}$

\section{Protection of Indonesian Migrant Workers}

One of the objectives of the state as stated in the Preamble of the 1945 Constitution is to protect the entire Indonesian citizen. Consequently, the state must provide protection of human rights. Protection of citizens' human rights includes the right to work and decent livelihood. It also covers the right to recognition, guarantee, protection and fair legal certainty, and equal treatment before the law, freedom to embrace and to worship according to religion, the right to communicate, get education, and so on.

This provision is affirmed in Article 27(2) of the 1945 Constitution, which reads "Every citizen shall have the right to work and to earn a humane livelihood". Next, Article $28 \mathrm{D}(1)$ states that "Every person shall have the right of recognition, guarantees, protection and certainty before a just law, and of equal treatment

\footnotetext{
Soeroso, Pengantar Ilmu Hukum, Jakarta: Sinar Grafika, 2006, p. 13.

Philipus M. Hadjon, op.cit, p. 5.

Abdul Khakim, Pengantar Hukum Ketenagakerjaan Indonesia Berdasarkan Undang-Undang Nomor 13 Tahun

2003, PT. Citra Aditya Bakti, Jakarta, p.26.

14 Asri Wijayanti, Hukum Ketenagakerjaan Pasca Reformasi, Jakarta: Sinar Grafika, 2009, p.8.
} 
before the law". It explicitly guarantees a person's right to obtain legal protection from the state. Furthermore, Article 28I(4) states, "The protection, advancement, upholding and fulfilment of human rights are the responsibility of the state, especially the government".

From the provisions in the constitution, it is clear that the protection of every citizen must be provided by the state wherever the citizen is and whatever they do. Through various legal instruments, the state seeks to provide legal protection for migrant workers. Legal protection is a protection of dignity and recognition of human rights for legal subjects based on legal provisions of arbitrariness. In addition, legal protection can also mean various legal efforts that must be given by law enforcement officials to provide security, both in physically and emotionally, from interference and various threats from any party.

The issuance of Protection of Indonesian Migrant Workers Law that replaces the Placement and Protection of Indonesian Migrant Workers Law is the government's latest effort to give more legal protection towards Indonesian migrant workers. Changes in legislation regarding the protection of migrant workers in Indonesia have gone through a long journey. It started from the involvement of the private sector in the placement of Indonesian labor migrants in the Regulation of the Minister of Manpower Number 4 of 1970 on Manpower Mobilization, in conjunction with the Regulation of the Minister of Manpower and Transmigration Number 1 of 1983 on Companies Deploying Indonesian Workers Abroad. They were amended several times, with the latest is the Decree of the Minister of Manpower by Minister of Manpower Number 104 of 2000 in conjunction with the Decree Number 104 A Year 2000 on the Placement of Indonesian Workers Abroad. The involvement of the private sector then increasingly gained legitimacy in the Placement and Protection of Indonesian Migrant Workers Law 2004. ${ }^{15}$ The involvement of the private sector is through the presence of the PPTKIS (Pelaksana Penempatan Tenaga Kerja Indonesia Swasta, or Private Indonesian Workers Placement). Unfortunately, this law that supposed to provide a protection toward migrant workers, is actually considered to weaken the protection of Indonesian migrant workers because it lessens the responsibility of the government. ${ }^{16}$

One of the main criticisms is that the Placement and Protection of Indonesian Migrant Workers Law emphasizes the aspect of placement more than the protection of migrant workers. Only 9 (nine) over 109 (a hundred and nine) articles of the Law contain aspects of protection. Even the nine articles are difficult to be implemented because they do not provide clear description. In addition, private

15 Lalu Husni, "Perlindungan Hukum terhadap Tenaga Kerja Indonesia di Luar Negeri", Mimbar Hukum, Vol. 23, No. 1, 2011, p. 156

16 Savitri Wisnuwardhani, Buku Saku Memahami Undang-Undang Perlindungan Pekerja Migran Indonesia: Kelebihan dan kelemahan UU PPMI, Jakarta: Jaringan Buruh Migran, 2018, p. 17. 
business actors carry out the permissibility of affairs that should be the responsibility of the government. In this case, the role of PPTKIS also became the spotlight of criticism.

For this reason, through the encouragement of various parties, especially migrant workers' organizations, the Placement and Protection of Indonesian Migrant Workers Law was finally scheduled to be revised in November 2010 on the agenda of the five-year National Legislation Program of the House of Representatives and become the Priority Program of legislation. The revision of the Law Number 39 of 2004 began to be discussed intensively in the Indonesian Parliament since 2012. On July 5, 2012, the Plenary Session of the Parliament ratified the revision of the Law into a Bill on the Protection of Indonesian Migrant Workers. This revision was not completed until the period ended in 2014. On January 9, 2015, in the Plenary Session, the House of Representatives stipulated the Revision of the Law Number 39 of 2004 to be included in the 2015 Program of legislation. For two years, the discussion at the level of the Working Committee involved Commission IX, several Ministries, and one agency (Ministry of Manpower, Ministry of Foreign Affairs, Ministry of Home Affairs, Ministry of Law and Human Rights, Ministry of Women and Child Empowerment, Ministry of Administrative Reform, Coordinating Ministry of Human Development and Culture, and BNP2TKI). Finally, on October 25, 2017, in the Plenary Session, the revision of the Law Number 39 of 2004 became the Law of the Indonesian Migrant Workers Protection. On November 22, 2017, the Protection of Indonesian Migrant Workers Law 2017 was declared effective and it replaced the Placement and Protection of Indonesian Migrant Workers Law 2004. ${ }^{17}$

In the Protection of Indonesian Migrant Workers Law 2017, the philosophy of migrant workers protection is reflected clearly in the section of consideration as follows:

a. that working is a human right that must be upheld, respected, and its implementation must be guaranteed as mandated in the 1945 Constitution of the Republic of Indonesia;

b. that the State ensures rights, opportunities, and gives protection to every citizen without discrimination to get a decent work and income, either in the country or abroad in accordance with the expertise, skill, talent, interest, and ability;

c. that Indonesian migrant workers must be protected from human trafficking, slavery and forced labor, violence, arbitrariness, crime against humanity, as well as other treatments that violate human rights;

d. that the placement of Indonesian migrant workers is an effort to achieve equal rights and opportunities for workers in order to get a decent work and income, 
of which implementation is conducted with regards to dignity, human rights, and legal protection, as well as equal job opportunities and supply of labor that is in accordance with the national interest;

e. that the State is obligated to improve the entire protection system for Indonesian migrant workers and their families which reflects the values of humanity and dignity as a nation before, during, and after working.

The philosophy of migrant workers' protection is then reaffirmed in Article 3, which reads "Protection of Indonesian Migrant Workers aims to: (a) ensure the fulfillment and enforcement of human rights as a citizen and Indonesian Migrant Worker; and (b) ensure legal, economic, and social protection for Indonesian Migrant Workers and their families".

\section{The Embodiment of the Philosophy of the Indonesian Migrant Workers' Protection in the Law Number 18 of 2017}

In contrast to Placement and Protection of Indonesian Workers Abroad Law, who were criticized for regulating more about placement rather than protection, the Protection of Indonesian Migrant Workers Law 2017 is clearly more focuses on the protection of migrant workers. The protection itself is regulated in Chapter III, which consists of 37 Articles. Article 7 of the Law states that Protection of Prospective Indonesian Migrant Workers or Indonesian Migrant Workers covers: (a) Prior to Work Protection; (b) Work Protection; and (c) After-Work Protection. This is in line with the definition of migrant workers, which includes every Indonesian citizen who will, is currently, or has done work by receiving wages outside the territory of the Republic of Indonesia.

\section{Prior to Work Protection}

The Article 8 of the Protection of Indonesian Migrant Workers Law 2017 divides 'prior to work' into two types of protections: administrative protection and technical protection. Administrative protection covers the completeness and availability of placement documents as well as the determination of conditions and work conditions such as marriage letters, family permit, health certificate, work competency certificate, passport, work visa, placement agreement, and work agreements. This is indeed important to note given that one of the main nodes of the problem of Indonesian migrant workers originated from poor documentation that caused many undocumented migrant workers become difficult to protect. While technical protection for migrant workers includes: (1) providing information and dissemination of information; (2) improving the quality of candidates for Indonesian Migrant Workers through work education and training; (3) Social Security; (4) Facilitating the fulfillment of the rights of Indonesian Migrant Workers; (5) strengthening the role of functional employees in the delivery of work; (6) 
placement services in one-stop integrated services placement and protection of Indonesian Migrant Workers; and (7) guidance and supervision.

Providing information and dissemination of information is an important manifestation of the rights of migrant workers to obtain information. Based on the World Bank survey in 2017, 39\% of migrant workers do not know the basic requirements and documents to become migrant workers. Meanwhile, $42 \%$ of migrant workers do not know the potential risks of working abroad. ${ }^{18}$

Furthermore, low-skilled migrant workers tend to go abroad with little knowledge of their specific job descriptions, rights, or even their wages. Therefore, the technical protection in regards with improving the quality of prospective Indonesian migrant workers through education and job training is also very crucial to be implemented.

One example of training that can be provided to migrant workers is the Training of Prospective Indonesian Migrant Workers Mental Strengthening initiated by the Ministry of Women's Empowerment and Child Protection of the Republic of Indonesia in collaboration with the International Organization for Migration (IOM). IOM Indonesia noted that in 2015 the numbers of prospective Indonesian migrant workers that successfully assisted by IOM are around 7,193 workers, consisting of 5,876 women and 1,317 men. It said that one victim might be reporting more than one cases, so that out of 20 types of cases, the total case reports reached 61,518 cases. The data from the National Agency for Placement and Protection of Indonesian Workers (BNP2TKI) mentions that in 2016 there were at least 4,756 Indonesian migrant workers that are facing problems abroad, 3,221 of them were female and 1,535 were male. ${ }^{19}$

The high number of case reports are not only due to employer's faults, but there are several internal factors that cause Indonesian migrant workers' still in weak position when it comes to bargaining position, especially women, in fighting for their rights. Many of these problems happen to Indonesian migrant workers who work in the informal sector, especially as domestic workers or housekeepers. In the informal sector, the legal protection for workers in the country of placement is still weak. ${ }^{20}$

Another important thing that is also regulated in Article 8 is about placement services in the one-stop integrated service (Layanan Terpadu Satu Atap - LTSA) for the placement and protection of Indonesian migrant workers. This is regulated in order to provide easy, inexpensive, fast, and safe placement and protection

\footnotetext{
World Bank, op.cit., p. 59.

19 Ministry of Women's Empowerment and Children Protection of Republic of Indonesia [Kementerian Pemberdayaan Perempuan dan Perlindungan Anak Republik Indonesia], "Press Release: Perkuat Mental Calon Pekerja Migran Indonesia", https://www.kemenpppa.go.id/index.php/page/read/29/1988/perkuat-mental-calon-pekerja-migran- 
services. The LTSA provides services in the management of document requirements and administration for the placement and protection of prospective and/or existing Indonesian migrant workers and together with the Central Government to recruit and to prepare services for administrative requirements.

The acceleration and downsizing of the documentation process will help to reduce the cost of migration and ultimately reduce the amount of non-procedural migration. Efforts to encourage procedural migration through the LTSA program are very promising. In addition, in order to function fully as a one-stop integrated service system, each LTSA office needs to have four components of the procedural migration process, which includes civil registration, employment records, health checks, and immigration.

Another breakthrough that needs to be appreciated is related to Social Security. According to Article 13 of the Protection of Indonesian Migrant Workers Law 2017, to be able to be placed abroad, Indonesian Migrant Workers are required to have some documents; one of which is a Work Agreement. Article 15 further explains that the contents of the work agreement must include the facilities and social security and/or insurance.

Moreover, the types of social security to be obtained by migrant workers are explained in Article 29 of the Law. In an effort to protect Indonesian Migrant Workers, the Central Government organizes Social Security for Indonesian Migrant Workers and their families. The implementation of the Social Security program for Indonesian Migrant Workers and their families is a part of the National Social Security System and is managed by the Social Security Organizing Agency. Certainly, this is a progress compared to the previous arrangement, in which insurance companies incorporated in the insurance consortium have carried out the protection of migrant workers' social security.

\section{Working Protection}

The second type of protection stipulated in the Protection of Indonesian Migrant Workers Law 2017 is protection during work. This protection is regulated in Article 21 and includes:

(1) data collection and registration by labour attaché or appointed foreign affairs official;

(2) supervision and evaluation on Employers, jobs, and work conditions;

(3) facilitation of the fulfillment of rights of Indonesian Migrant Workers;

(4) facilitation of the settlement of labour cases;

(5) provision of consular service;

(6) assistance, mediation, advocacy, and legal assistance provision in the form of advocate services by Central Government and/ or Indonesian Missions as well as guardianship in accordance with the local State law;

(7) development on Indonesian Migrant Workers; and 
(8) facilitation of repatriation.

The implementation of protection during work is different from other types of protection because it can only be carried out in accordance with the legislation and the law of the destination country, as well as international law and customs. Basic protection for Indonesian migrant workers is accessibility to information regarding the demands of migrant workers, both from business partners and prospective employers in the destination country. ${ }^{21}$

Article 22 states that in order to increase bilateral relationship in manpower and Protection of Indonesian Migrant Workers abroad, Central Government determines the labor attaché position in Indonesian Missions in certain countries. This is in line with the reality in the field, given the large number of current Indonesians working abroad; the steps to support migrant workers through consular services need to be improved.

In addition, the government can also expand the protection options for migrant workers through bilateral agreements. The research by the Global Knowledge Partnership on Migration and Development (KNOMAD) by the World Bank and the $\mathrm{ILO}^{22}$ show that bilateral agreements between sending and receiving countries can be effective tools in increasing and protecting the rights of migrant workers. Bilateral agreements, which regulate responsibilities and specific actions expected from both parties, can produce a legally binding understanding.

The enactment of the Protection of Indonesian Migrant Workers Law 2017 should be able to make the government more proactively involved in building cooperation with other countries, both sending countries and receiving countries. However, because this Law has only been implemented for less than two years, there is not enough data that can be used to show whether there has been an increase in government efforts to establish bilateral relations with related countries. It should be understood that both the sending and receiving countries have a responsibility to ensure the protection of migrant workers in accordance with the laws and policies in their respective countries. As with trade negotiations, Indonesia can also benefit from building strong cooperation with countries (especially neighboring countries) among senders of low-skilled labor. This is done in order to increase Indonesia's bargaining power with the recipient countries of labor, especially to ensure equal treatment of migrant workers with their own workers. $^{23}$

21 Ibid., p. 41.

22 Asian Development Bank Institute (et.al.), Labor Migration in Asia: Building Effective Institutions. Japan and United Kingdom: Asian Development Bank Institute, International, Labour Organization, and Organisation for Economic Co-operation and Development, 2016, p. 102.

23 World Bank, op.cit., p. 64. 


\section{After-Work Protection}

The third type of protection provided by the Protection of Indonesian Migrant Workers Law 2017 is after-work protection. One of the important objectives of after-work protection is to maintain the benefits of the migration that has been carried out by workforce. The benefits obtained from international labor migration cover various aspects, ranging from skills acquired while working abroad, life experiences gained while living abroad outside the routine of working and earning income, remittances sent to family members to support their welfare, and if possible, for long-term investments in the fields of education, health, and business capital. The government can play an important role in creating a conducive environment to support the use of the impact of migration on development and ensure the impact of sustainable remittances. ${ }^{24}$

In addition, policies are also needed to help migrant workers returning to Indonesia to be able to reintegrate into community and get guarantees for their rights as citizens. These are already embodied in Article 24, which stipulates that after work protection for migrant workers includes:

(1) facilitation of the repatriation until their hometowns;

(2) settlement of rights of Indonesian Migrant Workers that have not been fulfilled;

(3) facilitation of the arrangement of Indonesian Migrant Workers who are sick and dead;

(4) social rehabilitation and social reintegration; and

(5) empowerment of Indonesian Migrant Workers and their families.

Although it has not been clearly elaborated on the mechanism for implementing the above safeguards, it is clearly stated that the after-work protection is the responsibility of the Central Government together with the Regional Government.

From the description above, it is generally seen that the Protection of Indonesian Migrant Workers Law 2017 gives a bigger and more comprehensive role to the government, while reducing the role of the private sector in the placement and protection of Indonesian Migrant Workers. In the Placement and Protection of Indonesian Migrant Workers Law 2004, the role of the private sector was very dominant at all stages of migration, starting from providing information, registration, document management, conducting education, pre-departure, shelter, medical check-up, departure process, settlement problems, to returning. Because of the large role of the private sector, the state seems to be breaking hands in providing direct protection to migrant workers. This was one of the main

24 Ibid. p. 68. 
factors that put migrant workers/their families in vulnerable condition and became victims in various human rights violations. ${ }^{25}$

For example, the private sector often holds passports of migrant workers who are dispatched to work for security reasons. In fact, the detention of passports is very dangerous for migrant workers because it can be used as a deportation tool since they might be considered illegal workers who have no permit. Another example is that many PPTKIS dispatch underage migrant workers simply because of business considerations. These under-age workers not only violate the law but also are very vulnerable to exploitation or even experience human trafficking.

In the Protection of Indonesian Migrant Workers Law 2017, the state is affirmed its obligation to provide guarantee, protection, and fulfillment of the rights of migrant workers and their families by reducing the role of the private sector in the placement and protection. The role of the private sector is significantly reduced, so that the state is expected to play an ideal role as a protector of migrant workers. In the current Law, the governance of labor migration that was previously centralized is decentralized with the involvement of regional governments from provinces to villages. Strengthening the role of government at both the central and regional levels demonstrates the state commitments to provide protection to migrant workers and respect for human rights. ${ }^{26}$ Therefore, in general, this study agrees that the Law has reflected and embodied the philosophy of legal protection for Indonesian migrant workers.

\section{The Challenges of the Implementation of the Migrant Workers Protection based on the Law Number 18 Year 2017}

It has been explained that the provisions contained in the Protection of Indonesian Migrant Workers Law 2017 have sufficiently embodied the philosophy of protection for migrant workers. There are many advancements offered by the current Law compared to the previous Laws, especially in terms of giving more responsibility to the state to provide adequate legal protection. Even so, protection certainly does not stop only at the level of legislation. What is also crucial is ensuring the implementation of the Law. Based on the research conducted, there are at least three main challenges that need to be observed regarding the implementation of the provisions of this Law as follows.

\section{Challenges on One-Stop Integrated Services (LTSA) for Migrant Workers}

One of the breakthroughs stipulated in the Law of Migrant Workers Protection is the obligation of the government to hold a One-Stop Integrated Service (LTSA) to facilitate the departure and the return of Indonesian Migrant Workers. In order to

Savitri Wisnuwardhani, op.cit., p. 5.

Ibid. 
provide easy, inexpensive, fast, and safe placement and protection services, the LTSA performs services in accordance with the Law Number 25 of 2009 on Public Services and the Government Regulation Number 96 of 2012 on the Implementation of the Law Number 25 of 2009. The LTSA provides services in the management of document requirements and administration for the placement and the protection of prospective Indonesian migrant workers and/or labors and, together with the Central Government, to recruit and to prepare services of administrative requirements. ${ }^{27}$ According to Article 38 of this Law, the Central Government and the Regional Governments carry out the service of placing and protecting Indonesian migrant workers in a coordinated and integrated manner. The LTSA is a mandate to the Regional Governments.

The challenge that arises from the enactment of this rule is because, in practice, the LTSA needed a large effort in its development. In addition, there is no clear standard for implementing the LTSA itself. Based on the observations in several LTSA located on the Kalimantan borders, there were several LTSA that do not meet the standards because workers still have difficulties in managing their own work documents and still needed brokers/sponsors to handle documents in the LTSA.

\section{Implementation of Social Security through the BPJS Ketenagakerjaan}

One of the biggest challenges in implementing BPJS Ketenagakerjaan ${ }^{28}$ for migrant workers is how to provide protection to migrant workers while they are abroad. Given that migrant workers are physically outside the territory of Indonesia when they work, special arrangements are needed between BPJS as an administrator and insurance providers in the destination country. Therefore, BPJS needs to enter into bilateral agreements with parties from destination countries. Inter-governmental memorandum of understanding ( $G 2 \mathrm{G} \mathrm{MoU}$ ) must consider the ability of employers to pay contributions, social security regulations in each country, and how to coordinate benefits and contributions, as well as service and administration (for example, agreements between Moldova and Italy, Portugal or other countries receiving migrant workers in the European Union). ${ }^{29}$ In addition, according to Migrant Workers Network, there are several differences of rights or benefits for migrant workers in terms of social security compared to domestic workers as follows. ${ }^{30}$

\footnotetext{
See General Eludication of Manpower Protection Law.

BPJS stands for Badan Penyelenggara Jaminan Sosial (Social Insurance Administration Organization). There are two versions of BPJS: BPJS Kesehatan and BPJS Ketenagakerjaan. The first administers social insurance for nonemployees/self employed/informal workers and the latter for employees. Both are government insurance companies formed by the Law Number 24 of 2011.

29 World Bank, op.cit., p. 103.

30 Savitri Wisnuwardhani, op.cit., p. 61.
} 
1. The premium of BPJS is fully borne by Indonesian migrant workers. Domestic workers/laborers only bear a portion because of the payment is divided to employers and workers;

2. Guarantees of accident (JKK) for domestic workers provide benefits even though they only experience minor accident. Migrant workers do not receive equal treatment and only receive treatment/treatment after arriving in Indonesia.

3. Guarantees of casualties for migrant workers can only be obtained if workers experience anatomic disabilities such as fractures, dozens of organs.

4. BPJS Ketenagakerjaan supposed to have Return to Work (RTW) program. This program is specifically given to victims of workplace accidents who are no longer able to work in their original places so that special training is needed so that they can be placed in other sections. However, this treatment does not apply to migrant workers.

5. BPJS Ketenagakerjaan has a PAK program to handle occupational illness. Occupational illness is any illness that is seen after several years after work. Domestic workers/laborers can claim this program even though they have not worked for three years. Unfortunately, migrant workers cannot access the program, even though a lot of migrant workers cases are about being sick because of exposure to chemicals that leading to prolonged illness. Migrant workers do not benefit from this program even though it is very affordable for work-related diseases.

6. The Regulation of the Minister of Manpower related to BPJS also does not include health insurance that can be accessed by migrant workers in the destination country. In the case, employers insure not all migrant workers. When a migrant worker is sick or hospitalized, the worker will cover all costs. In some countries, the cost of non-citizens health costs is up to $300 \%$ and must be paid in advance, at the beginning of treatment.

7. BPJS Ketenagakerjaan does not bear the risks that are often experienced by migrant workers such as failure to leave, failed placement, unilateral layoffs, unpaid salaries, and legal issues. In the previous Regulation of the Minister of Manpower, the risks were borne by a private insurance. Currently, since the BPJS Ketenagakerjaan does not cover the things mentioned above, the PPTKIS insures to Askrindo for cases of failed placement, non-departure, unilateral firing, and unpaid salaries. The benefits of Askrindo insurance are given to the PPTKIS as the guarantor. The migrant workers do not receive the benefits that were previously obtained.

8. Transportation costs as outlined in the Regulation of the Minister of Manpower Number 7 of 2017 are very minimal while migrant workers' locations are most likely difficult to access. 
9. Benefits for migrant workers who die or have a disability are still discriminatory if compared to domestic / non-migrant workers. For example, the amount of scholarships for non-migrant workers' children reaches Rp12 million in a year. While comparing to migrant workers scheme, there is only one child that will receive the scholarship in the event of migrant workers death, covering annually Rp500,000 in primary school, Rp750,000 in secondary school, $\mathrm{Rp} 1,000,000$ in high-school, and $\mathrm{Rp} 1,500,000$ in university. The financing scheme does not meet current educational needs.

10. The Regulation of the Minister of Manpower Number 7 of 2017 does not regulate the existence of an appeal mechanism for justice seekers in submitting financial claims when compared to the previous Regulation.

From the points above, it appears that the government still have a lot of homework in relation with social security, so that this policy might be implemented effectively. One of the ways to do it is by designing a migrant worker insurance scheme for risks that cannot be borne by the BPJS Ketenagakerjaan. The reality shows that a number of incidents related to un-insurable risks is still significant and, therefore, cannot be ignored. Hence, it is very important for the government to find solutions to ensure the protection of migrant workers against these risks. Additional schemes to cover uninsured risks outside the BPJS Ketenagakerjaan scheme, such as termination of employment contracts, physical abuse, and sexual harassment, may need to be carried out by other private or government institutions, other than the BPJS itself. ${ }^{31}$

\section{Challenges Related with Access to Justice for Migrant Workers}

Another challenge that might potentially emerge from the Protection of Indonesian Migrant Workers Law 2017 is related with access to justice for migrant workers. The law has not yet been regulated clearly regarding the special mechanism to obtain justice. For example, how do migrant workers make civil law claims against PPTKIS in the event of a violation of their employment agreement, or what migrant workers need to do if they want to go through criminal procedure. Protection of Indonesian Migrant Workers Law 2017 only regulates in general about Settlement of Disputes by means of deliberation, through the local labor agency, until the lawsuit is filed against the Court.

Moreover, the government need to further elaborate about the access to legal assistance for migrant workers. In the Law, regulations of legal assistance are only mentioned once in Article 21(1)(f) related to Protection During Work, which reads "assistance, mediation, advocacy, and legal assistance provision in the form of advocate services by Central Government and/ or Indonesian Missions as well as guardianship in accordance with the local State law". The Law regulates the right of

31 World Bank, op.cit., p. 66. 
assistance, mediation, advocacy, and the provision of legal assistance in the form of advocacy services by the Central Government and/or Representative of the Republic of Indonesia in Part Three entitled During Working Protection. Therefore, it is assumed that migrant workers will only obtain the legal entitlement during the period of their employment. It does not cover the period before work and after return, even though in reality, there are also many problems that are very likely to be faced by migrant workers during the before and after working period.

Furthermore, the arrangements contained in Article 21(1)(f) of the Law are still very general in nature. Therefore, it is necessary to elaborate them more specifically through the implementation of the regulations. This is in line with the mandate stated in Article 23 of the Law, which states "Further provisions regarding the procedures for During Working Protection as referred to in Article 21 are regulated with Government Regulation".

Besides the three main challenges outlined above, this study sees a number of other important things to observe so that the implementation of the Law Number 18 of 2017 can run optimally. One of them is related to the increasingly crucial role of the Representative of the Republic of Indonesia and the Labor Attache to be the spearhead of the protection of Indonesian migrant workers abroad. Therefore, it is important to make sure that all of Labour Attaché have a human rights perspective, where they must respect, protect, and fulfill the human rights and fundamental freedoms of every Indonesian migrant worker, in accordance with international human rights standards.

In addition, the Law states various types of administrative sanctions, such as written warnings, temporary termination for part, or all business activities, and revocation of licenses of PPTKIS. However, it should be noted that the enforcement of administrative sanctions is often difficult because of complicated bureaucracy in the Ministry of Labour. Therefore, to ensure a more effective implementation of sanctions, the government needs to regulate the simpler mechanism and more enforceable sanctions.

Another important thing that is absolutely necessary for effective implementation of the Migrant Workers Protection Act is the immediate issuance of implementing regulations. This is because there are so many articles in this Law that still need further regulation. These implementing regulations certainly should not conflict with the spirit of protection of migrant workers who have been presented in the Protection of Indonesian Migrant Workers Law 2017.

\section{E. Conclusion}

Protection of Indonesian Migrant Workers Law 2017 in general has given a bigger role to the government, while reducing the role of the private sector in the placement and protection of Indonesian migrant workers. The Law affirms the state's obligation to guarantee, protect, and obtain rights of migrant workers and 
their families by reducing the role of the private sector in the placement and protection of migrant workers. Strengthening the role of the government shows the state's commitment to provide protection to migrant workers and respect for human rights. This study generally agrees that this Law has reflected and embodied the philosophy of protection law for Indonesian migrant workers properly.

However, there are three crucial challenges of implementing the protection of migrant workers as stipulated in the Law that are related with: (1) the implementation of One-Stop Integrated Services (LTSA) for Migrant Workers; (2) implementation of social security through BPJS Ketenagakerjaan; and (3) access to justice for migrant workers abroad.

Considering that many articles in the Law Number 18 Year 2017 still require further regulation, it can be suggested that the government immediately makes implementing regulations for this Law. Implementing regulations are absolutely necessary so that the implementation of the Law of Migrant Workers Protection can be effective and enforced immediately. Historically, the problems that previously appeared in the Placement and Protection of Indonesian Migrant Workers Law 2004 were not only due to the Laws but because the implementing regulations did not uphold the spirit of legal protection which in line with human rights. Therefore, the implementing regulations of the Law need to be made carefully, preferably by involving migrant worker organizations that are directly engaged in the field, so that it will not conflicted with the spirit of migrant workers protection that have been presented in the Protection of Indonesian Migrant Workers Law 2017.

\section{References}

\section{Books}

Abdul Khakim, Pengantar Hukum Ketenagakerjaan Indonesia Berdasarkan UndangUndang Nomor 13 Tahun 2003, PT. Citra Aditya Bakti, Jakarta, 2003.

Asian Development Bank Institute (et.al.), Labor Migration in Asia: Building Effective Institutions, Asian Development Bank Institute, International, Labour Organization, and Organisation for Economic Co-operation and Development, Japan and United Kingdom, 2016.

Asri Wijayanti, Hukum Ketenagakerjaan Pasca Reformasi, Sinar Grafika, Jakarta, 2009.

Malinowski, Bronislaw, Crime and Custom in Savage Society, Trench, Trubner and co. Itd, London, 1926.

Philipus M. Hadjon, Perlindungan Hukum Bagi Rakyat di Indonesia, PT. Nila IImu, Surabaya, 1987.

Pusat Penelitian dan Pengembangan Kesejahteraan Sosial, Badan Pendidikan dan Penelitian Kesejahteraan Sosial, Perlindungan Sosial Pekerja Migran 
Bermasalah Melalui Rumah Perlindungan Trauma Center, Kementerian Sosial Republik Indonesia, Jakarta, 2015.

Savitri Wisnuwardhani, Buku Saku Memahami Undang-Undang Perlindungan Pekerja Migran Indonesia: Kelebihan dan kelemahan UU PPMI, Jaringan Buruh Migran, Jakarta, 2018.

Soeroso, Pengantar Ilmu Hukum, Sinar Grafika, Jakarta, 2006.

World Bank, Laporan Bank Dunia Indonesia: Pekerja Global Indonesia: Antara Peluang dan Resiko, World Bank Group, Jakarta, 2017.

\section{Other Documents}

Badan Nasional Penempatan dan Perlindungan Tenaga Kerja Indonesia (BNP2TKI -The National Agency for Placement and Protection of Indonesian Workers), "Data Penempatan TKI Tahun 2011 sampai dengan 2016", http://www.bnp2tki.go.id/uploads/data/data 08-02-2017 111324 Data-

P2TKI tahun 2016.pdf, accessed on March 2019.

Hotman Siregar (ed.), "Menteri Yohana Ungkap 7 Kelemahan UU TKI", http://www.beritasatu.com/nasional/287806-menteri-yohana-ungkap-7-

kelemahan-uu-tki.html, accessed on July 2018.

Kompas. Id, "Tahun 2017, Kasus yang Menimpa Pekerja Migran Capai 7.600", https://kompas.id/baca/utama/2018/02/25/tahun-2017-kasus-yang-menimpapekerja-migran-capai-7-600/, accessed on March 2019.

Lalu Husni, "Perlindungan Hukum terhadap Tenaga Kerja Indonesia di Luar Negeri", Mimbar Hukum, Vol. 23, No. 1, 2011.

Ministry of Women's Empowerment and Children Protection of Republic of Indonesia [Kementerian Pemberdayaan Perempuan dan Perlindungan Anak Republik Indonesia], "Press Release: Perkuat Mental Calon Pekerja Migran Perempuan

Indonesia",

https://www.kemenpppa.go.id/index.php/page/read/29/1988/perkuat-

mental-calon-pekerja-migran-perempuan-indonesia, accessed on March 2019.

\section{Legal Documents}

The 1945 Constitution of Republic of Indonesia.

Law Number 37 of 1999 on Foreign Relations [Undang-Undang Nomor 37 Tahun 1999 tentang Hubungan Luar Negeri].

Law Number 13 of 2003 on Manpower [Undang-Undang Nomor 13 Tahun 2003 tentang Ketenagakerjaan].

Law Number 39 of 2004 on Indonesian Migrant Workers Placement and Protection [Undang-Undang Nomor 39 Tahun 2004 tentang Penempatan dan Perlindungan Tenaga Kerja Indonesia di Luar Negeri].

Law Number 6 of 2012 on the Ratification of International Convention on the Protection of the Rights of All Migrant Workers and Members of Their Families 
[Undang-Undang Nomor 6 Tahun 2012 tentang Pengesahan International Convention on the Protection of the Rights of All Migrant Workers and Members of Their Families (Konvensi Internasional Mengenai Perlindungan Hak-Hak Seluruh Pekerja Migran Dan Anggota Keluarganya)].

Law Number 18 of 2017 on the Indonesian Migrant Workers Protection [UndangUndang Nomor 18 Tahun 2017 tentang Perlindungan Pekerja Migran Indonesia].

Government Regulation Number 3 of 2013 on the Indonesian Migrant Workers Protection [Peraturan Pemerintah Nomor 3 Tahun 2013 tentang Perlindungan Tenaga Kerja Indonesia di Luar Negeri]. 